\title{
Latin American countries and the establishment of the multilateral trading system: the Havana Conference (1947-1948)
}

\author{
Países latino-americanos e o acordo internacional \\ de comércio: a Conferência de Havana (1947-1948)
}

NORMA BREDA DOS SANTOS*

RESUMO: Este artigo se propõe a estudar a participação dos países latino-americanos na Conferência de Havana, que negociou e aprovou a Carta da Organização Internacional do Comércio (OIC), incluindo o Acordo Geral sobre Tarifas e Comércio (GATT), em 1947-1948. O trabalho mostra que o entendimento predominante entre as delegações latino-americanas era o de que as negociações de Havana seriam o resultado das assimetrias de poder material e político existentes entre os seus países e os países industrializados. Os latino-americanos acreditavam que as suas economias frágeis deviam enfrentar as fortes economias dos países industrializados através de planejamento econômico e da substituição de importações, já em vigor em vários países latino-americanos desde as décadas de 1930 e 1940. O trabalho mostra ainda que a construção do regime de comércio internacional pós-Segunda Guerra Mundial foi de fato caracterizado por fortes desigualdades materiais e políticas, que prejudicaram a capacidade de negociação dos países latino-americanos.

PALAVRAS-CHAVE: Conferência de Havana; GATT; comércio internacional; Acordo da Organização Internacional do Comércio; países da América Latina; o multilateralismo; liberalismo enraizado.

ABSTRACT: This article proposes to study the participation of Latin American delegations during the Havana Conference, which negotiated and approved the Charter of International Trade Organization (ITO), including the General Agreement on Tariffs and Trade (GATT), in 1947-1948. It shows that the prevalent understanding of Latin American countries was that the Havana negotiations would be the outcome of their existing political and material power asymmetries in relation to the industrialized countries. They believed that their fragile economies should face the strong economies of the industrialized countries by economic planning and import substitution, already in place in several Latin American countries since the 1930s and the 1940s. The article also shows that the construction of the post-World

* Instituto de Relações Internacionais da Universidade de Brasília, e-mail: normabs@gmail.com. Submmited: 13/March/2014: Approved: 17/April/2015. 
War II international trade regime was in fact characterized by strong material and political inequalities, which undermined Latin American countries abilities to negotiate.

KEYWORDS: Havana Conference; GATT; international trade; ITO Charter; Latin American Countries; Multilateralism; embedded liberalism.

JEL Classification: F-13.

The Bretton Woods agreements in 1944, the General Agreement on Tariffs and Trade (GATT) in 1947, and the World Trade Organization (WTO) in 1995 were developed under a liberal perspective that has dominated the international agenda since the end of World War II. The liberal consensus indicates how the support for international free trade would be a confirmation not only of American supremacy, but also of its legitimate international leadership.

During the Havana Conference on Trade and Employment (Havana Conference) held in 1947-1948, the Charter of the International Trade Organization (ITO) was approved. The international organization's agenda covered a large number of issues, including full employment, labour criteria, restrictive business practices, intergovernmental commodity agreements, and investments. The ITO never came into being, but the text of the GATT, which was supposed to be incorporated into the ITO Charter, came into force in January 1948. Thus, only the legal framework for postwar international commercial relations remained.

The American ITO architects assumed that multilateral trade cooperation would entail global economic prosperity, thereby ending poverty and preventing war. However, for developing countries, and specifically for Latin American governments, which constituted a numerical majority ${ }^{1}$ of the Havana Conference and its "bulk" (Hudec, 1987, p. 22), neoclassical economic beliefs had been weakening significantly since the beginning of the 1930s. Moreover, in their view, World War II had confirmed the importance of economic planning and the development of a national industry. This explains why the structuralist economic orientation found fertile land in Latin America in the 1940s and the decades thereafter.

Studies on the Havana Conference have mostly focused on the bargaining process of the United States, the United Kingdom, and other industrialized countries (Wilcox, 1949; Diebold, 1952; Gardner, 1956; Irwin, 1995; Aaronson, 1997; Zeiler, 1998, 1999; Miller, 2000, 2003; Deese, 2008; Irwin, Mavroidis and Sykes, 2008), with very small attention given to the participation of developing countries. Few studies have contributed more resolutely to the understanding of the positions of non-hegemonic countries (Brown, 1950; Diebold Jr., 1952; Evans, 1968; Curzon, 1969; Elkin, 1984; Hudec, 1987; Capling, 2000, 2001; Scott, 2009; Kim, 2010;

\footnotetext{
${ }^{1}$ Of the total 57 delegations in Havana, seventeen were from Latin America - almost one third Argentina, Bolivia, Brazil, Chile, Colombia, Costa Rica, Cuba, Dominican Republic, Ecuador, El Salvador, Guatemala, Mexico, Nicaragua, Panama, Peru, Uruguay and Venezuela. National Archives (NA), “United Nations Conference on Trade \& Employment”, Department of Public Information, Havana, Cuba, E/CONF.2/BUR/39U. RG 43, RICCE, Box 139.
} 
Farias, 2012, 2014), although Richard Gardner (1956, pp. 378-379), in his seminal work on the history of the U.S.-U.K. collaboration for the creation of the International Monetary Fund (IMF) and the Havana Charter, considered that one of the principal causes for the ITO's demise was "the failure to devote more attention at the very outset to the economic needs of the under-developed countries".

The objective of this article is to study the participation of Latin American delegations during the Havana Conference. The article argues that the prevalent understanding of Latin American countries was that the Havana negotiations would be nothing but the outcome of their existing political and material power asymmetries in relation to the industrialized countries. It also argues that the negotiations for the construction of the new international trade regime were themselves characterized by strong and marked inequalities.

This study is made up of three parts. The first one synthesizes the contending bilateral negotiations between the U.S. and U.K. officials that resulted in the "Proposals for Expansion of World Trade and Employment". These Proposals, which called for an international conference to negotiate the reduction of governmental barriers to trade and to establish the ITO, containing already the principles and rules to be multilaterilized in Havana, were published in December 1945. This was the moment when the two main rule makers established the boundaries of embedded liberalism, a term widely used by mainstream International Relations literature to characterize the postwar economic order, involving a quest for a combination of domestic stability and liberalization abroad (Ruggie, 1982, 1992, 2003). The second part shows that the Latin American countries' arrival in Havana was characterized by their frustration, since it became clear that the U.S. economic aid they expected for their support during World War II would not be given. Latin American countries had a rather critical perception of the trade regime that was being created - a regime that would not address their need for diversifying their economies, instead favouring industrial countries. The third part examines the way Latin American and U.S. negotiators interacted in Havana and how they perceived each other, also showing the Latin American countries' material and political constraints which undermined their ability to negotiate.

Policy formulation and decision-making processes in the different countries mentioned along the text will not be examined, which does not mean that States are viewed as monolithic entities. Countries' governments are structured in bureaucratic agencies, as departments and ministries, with different institutional roles, reflecting different interests; Congress, or Parliament, plays different roles and has different relative power in different countries. Leaders' personalities and public opinion are also important factors in policy formulation and decision-making processes ${ }^{2}$

This paper is based on the official Havana Conference and U.S. diplomatic documentation found at the National Archives (NA, College Park, MD). It is also

\footnotetext{
${ }^{2}$ See in Irwin, Mavroidis, Sykes (2008, pp. 22-27) a good description of the U.S. and the UK policy formulation and decision-making process.
} 
based on the Brazilian diplomatic papers available at the Brazilian Ministry of Foreign Affairs' Historical Archives (Itamaraty, Rio de Janeiro). In the post-war context, Brazil was undergoing experiences that were common to other countries of the continent, where the desire for economic diversification and modernization was the foundation for the development of what was later called dependency theory. At the same time, Brazilian diplomacy's perception was that the U.S. delegation should give Brazil a highlighted role in negotiations. Latin American positions are also studied through the related specialized bibliography.

\section{AMERICANS AND BRITONS, AND THE EMBEDDED LIBERALISM}

In the early 1990s, John G. Ruggie (1992), one of the most influential International Relations theorists ${ }^{3}$, called attention to the fact that, contrary to what realists and neo-realists would predict, the collapse of the Soviet Union and the end of Cold War had happened peacefully, and that it was quite consensual that multilateral norms and institutions had played a relevant role in accommodating the fundamental geopolitical changes and in stabilizing the post-Cold War world system. ${ }^{4}$

Based on William Diebold's formulation, Ruggie attributes a qualitative or substantive dimension to the conventional, nominal, or formal definition of a multilateral institution, which focuses on the participating number of states - three or more states that coordinate their national policies. He insists on the relevance of the "kind" of relations existing among the states of a multilateral arrangement or the organizing principles instituted among them.

According to Ruggie, what distinguishes post-World War II international relations is the creation of several multilateral institutions - the United Nations and the Bretton Woods institutions (the World Bank and the IMF) -, organized under U.S. leadership and the compromise of embedded liberalism. According to Ruggie,

to say anything sensible about the content of international economic orders and about the regimes that serve them, it is necessary to look at how power and legitimate social purpose become fused to project political authority into international system. Applied to the post-World War II context,

\footnotetext{
${ }^{3}$ See Griffiths, Roach, Solomon (2008): Fifty Key Thinkers in International Relations.

${ }^{4}$ The discussion on multilateralism is linked to what in International Relations is called the "regime theory", which aims at explaining international co-operation. Although it is difficult to label Ruggie in the development of the International Relations Theory, it can be noted that his work is opposed to the rationalistic propositions and is one of the most important thinkers of social contructivism. According to Ruggie (2003, xi), "constructivists hold not only that the interests and the preferences of actors are socially constructed but that they must share the stage with a whole host of other ideational factor [, and, citing Max Weber], “to take a deliberate attitude towards the world and lend it significance"” [1949, emphasis in Weber original].
} 
this argument leads me to characterize the international economic order by the term "embedded liberalism" [...]. (Ruggie,1982, pp. 382-383).

Karl Polanyi (The Great Transformation, 1944) characterized the tragic interwar years by the unsuccessful international efforts to restore the golden-exchange standard, when markets and a laissez-faire attitude had been taken to an extreme and become "dis-embedded" from society, or that it lacked a social basis. ${ }^{5}$ Ruggie adapted Polanyi's concept to explain that the "liberalism that was restored after the World War II differed in kind from that which had known previously" (1982, p. 392).

This was the essence of the embedded liberalism compromise: unlike the economic nationalism of the thirties, it would be multilateral in character; unlike the liberalism of the gold standard and free trade, its multilateralism would be predicated upon domestic intervention (1982, p. 393).

With the GATT regime, tariff reductions would be bilaterally negotiated and then extended to all other parties of the agreement under the basis of most-favorednation (MFN) treatment. According to Ruggie, this has to do with two corollaries that follow his definition of multilateralism: the indivisibility of the behavior expected of the members of the multilateral arrangement, and what Robert Keohane has called "diffuse reciprocity", which is some equivalence of the benefits the States of a multilateral institution expect to receive over time (Keohane, 1986).

Nevertheless, if the post-World War II international trade regime can be understood under the notion of embedded liberalism, this does not explain how the search for freer world trade was balanced with protection and other policies, as Charles Lipson points out, stating that that two key points remain:

One is to define the forms of illiberal protection. The second is to differentiate embedded liberalism from illiberalism in practice. Unless one is examining a long-term trend, it may be impossible to tell whether specific trade barriers are (1) illiberal steps toward broader protection, or (2) simply efforts to moderate the impact of the world market on domestic society (Lipson, 1983, p. 241).

\footnotetext{
${ }^{5}$ For Polanyi, pre-modern economies reflected the basic principles and values of society - "a function of the social" -, while modern market economy and modern nation-state, inextricably linked, implied the invention of what he called "market society", disembedded from social order and where market is central to society's functions. Polanyi's "thesis is that the idea of a self-adjusting market implied a stark utopia” (2001 [1944], p. 3). Despite Polanyi wrong assertions and predictions, such as the end of capitalism internationalism, his ideas still nowadays resonate in debates on public policy. Besides, as Ruggie (1982, p. 388) asserts, Polanyi was correct, as Harry Dexter White and John Maynard Keynes, in the "premisse that, somehow, the post-war international economic order would have to reflect [the] changes in state-society relations if the calamities of the interwar period were not to recur."
} 
It would be important, therefore, to focus on the distributional aspects of the provisions of the Havana Charter that would create the ITO and the GATT frameworks. Indeed, Ruggie takes into consideration Lipson's critics and emphasizes that his focus is on the industrialized world when developing the concept of embedded liberalism, while stating that " $[\mathrm{t}]$ he compromise of embedded liberalism has never fully extended to the developing countries. [...] Moreover, the liberalization produced by the GATT has benefited relatively few among them" (1982, pp. 413-414). In other words, it would be important to focus on the distributional aspects of the gains from the provisions of the GATT, as well as on their disruptive domestic adjustment costs, not to mention the commitments related to the liberalization of agriculture - which never comes true - or the deviation from the trade regime rules with the "voluntary" textile export restraints that prevailed until recently.

It should be added that before the multilateral ITO Conference of 1947-1948 and its three multilateral preparatory meetings (London, New York and Geneva), bilateral negotiations took place between the U.S. and U.K. officials which resulted in the "Proposals for Expansion of World Trade and Employment", published in December 1945. Produced by Americans and Britons, the Proposals were then the fundamental document upon which the following multilateral negotiations were based. Its content reflects the rules obtained after struggles between the two main rule makers of the new international trade system and, consequently, the main boundaries of the embedded liberalism.

Therefore, the delimitation of the embedded liberalism - the borders established between liberalization abroad and domestic state activism - was first negotiated between the U.S. and the U.K. in 1945. The result of these talks would be the starting point for the multilateral preparatory meetings for Havana and the Havana Conference itself. It should then be stressed how the U.K. protectionist policies were accepted or limited by the Americans in 1945, before looking at the 1946 to 1947 negotiations and their results.

The American ITO architects believed the world could not prosper only via the reduction of obstacles to international trade. Nevertheless, the U.S. government was anxious for the prospects of American exports benefiting from liberalizing international trade (Feiss, 1948, p. 40). During the years of intense preparation for war, the proportional place of the U.S. in world trade had been declining: in 1945, it corresponded to 6.6 percent of the American gross domestic product (Table 1). 
Table 1 - United States Total Trade as a Percentage of Gross National Product*

\begin{tabular}{|c|c|c|c|}
\hline Year & Total Trade & GNP & \% of GNP \\
\hline 1940 & $\$ 72$ & $\$ 773$ & 9.3 \\
\hline 1945 & $\$ 89$ & $\$ 1,355$ & 6.6 \\
\hline 1950 & $\$ 114$ & $\$ 1,204$ & 9.5 \\
\hline 1955 & $\$ 154$ & $\$ 1,495$ & 10.3 \\
\hline 1960 & $\$ 48.1$ & $\$ 513.0$ & 9,3 \\
\hline 1970 & $\$ 112.8$ & $\$ 1.010,7$ & 11.1 \\
\hline 1980 & $\$ 573.1$ & $\$ 2,708.0$ & 21.2 \\
\hline 1990 & $\$ 1,086.0$ & $\$ 5.546,1$ & 21.4 \\
\hline
\end{tabular}

* In billions of 1993 dollars.

Source: Council of Economic Advisors, Economic Report of the President: Transmitted to the Congress,

February 1994 (Washington D.C. GPO 1994, pp. 268-269, apud Aaronson 1996, p. 8).

When World War II ended, the U.S. was by far the world's biggest economy and military power. The U.K.'s economic and military position had suffered a drastic deterioration and was much weaker, needing the American assistance. Nonetheless, the U.K. succeeded in obtaining vital concessions from the U.S. in negotiating the new trade regime. The reasons for the U.K.'s success in obtaining concessions on key issues such as imperial preferences, quantitative restrictions, cartels and state trading have been one of the important matters studied directly or indirectly in papers examining the creation of the ITO and the GATT.

For Gardner, the reason for the U.K.'s success in obtaining what they wanted on trade issues comes from the U.S. domestic front and strategic considerations. For him, by 1947, the U.S. was

in a difficult position. [...] The co-operation of Congress would be needed to facilitate modifications in the Anglo-American Financial Agreement [American financial assistance to the U.K.]. It would be needed also to pass the program of Marshall Aid [...] (1956, pp. 357-358).

Thomas Zeiler also calls attention to the pressure at home, but major emphasis is given to the U.S. officials' need to strategically compromise with U.K. pressure when the Cold War began. Then,

$[\mathrm{u}]$ nfortunately for free-traders the constant pressure for protectionism and the ideological background of the Cold War shifted America's trade objectives from peace to security. Realism and national security, not idealism and economic theory, took precedence in decisions $(1999$, p. 3).

James Miller argues that the major trade exceptions were obtained by the U.K. from the world's most powerful nation in their bilateral talks of the final months of 
1945, which resulted in the "Proposals for Expansion of World Trade and Employment", calling for an international conference to negotiate the reduction of governmental barriers to trade and to establish the ITO, published in December 1945.

The U.S. and U.K. formal negotiations began in October 1945, based on a draft prepared by the State Department containing provisions discussed in informal wartime bilateral talks. Despite the fact that the U.K. was crippled in the war, that President Truman had terminated Lend Lease (August), and that the U.K. desperately required American financial assistance, big concessions were obtained from the U.S. in the Washington negotiations. The final version of the Proposals deeply amended its draft, and the U.S.-U.K. loan negotiations of $\$ 3.75$ billion were successfully finalized at the same time (Douglas, Mavroidis and Sykes, 2008, p. 71).

For Miller, the U.K. overcame elements of the U.S. hegemony and hard diplomacy - military, political and economic prestige - with negotiating skills and strategic thinking.

[T] hey effectively applied 'soft' diplomacy in the actual negotiations. [... They] resisted American demands with a combination of lucid arguments (presented to a receptive audience), pragmatism (versus American idealism), bluff (in the face of American openness), plain stubbornness (aided by American flexibility) [...].

Once obtained, concessions would not be reversed. The U.K. insisted to transform an ostensibly bilateral negotiation into a multilateral forum where Britain and its allies outnumbered the U.S. by a factor of five to one. [...]

Americans unwittingly elevated their desire for international collaboration to the same level as their advocacy of free trade principles. The State Department simultaneously advocated a multilateral process and liberal trading principles. Yet they failed to recognize the tension at the core of this dual program, and thus they never considered the trade-offs involved in securing both aims. The British, however, were conscious of this conflict [and knew that in a multilateral arena its] power would be augmented by its ability to form coalitions that challenged U.S. ideals (2000, p. 3; emphasis added).

The abolition of the imperial preferences was supposed to be central and the first U.K. commitment so as to obtain the U.S. loan. Still, "[ $t]$ he British representatives resisted this effort, citing the close ties of kinship that bound Britain to the people of Canada, Australia, and New Zealand" (Irwin, Mavroidis and Sykes, 2008, p. 39) [principally, South Africa should be added] and, instead, the imperial preferences $^{6}$ were maintained with the language that "no preferences would be created

\footnotetext{
${ }^{6}$ The imperial preference system, established by the Ottawa Agreement of 1932, was supposed to be a temporary response to the Hawley-Smoot Tariff act of 1930, which pushed the commercial policies of
} 
nor existing preferences increased"; no deadline was set for their abolition. ${ }^{7}$ The U.K. officials also obtained fewer restrictions on the use of import quotas for balance-of-payments. Cartels were not banned outright and would be examined on a case-by-case basis by the ITO, and vague language allowed for maintaining state trading practices, subsidies and export taxes. Once obtained, the concessions would not be reversed. As important as the indulgence on trade liberalization and other trade-related concessions obtained by U.K. officials, the compromise with the U.S. to transform the bilateral negotiations into a multilateral forum was crucial, since the U.K. would enhance its bargaining power as the leader of a coalition formed with its dominions.

\section{"LATINOS": LOOKING FOR MODERNIZATION AND STABILITY}

The three multilateral meetings preparing for the creation of the global trade regime convened in London (First Preparatory Meeting), in October and November 1946, in New York (Second Preparatory Meeting), in January and February 1947, and in Geneva (Third Preparatory Meeting), from April to October 1947. The Havana Conference took place from November 1947 to March 1948. Concurrently with issues such as labour criteria, restrictive business practices, intergovernmental commodity agreements and investments, the GATT - about trade barrier reductions - was being negotiated. The GATT was completed and signed at the end of 1947 as an interim agreement, and it came into force in January 1948.

In Havana, among the fifty-seven delegations eligible to sign the Final Act of the Conference, forty-one were from developing countries. ${ }^{9}$ When describing the opening of the Conference, the Americans mention "a widespread rejection of the Charter, principally by Latin-American countries and other undeveloped countries." ${ }^{10}$

\footnotetext{
many countries to look for protecting their economy from the Great Depression effects. Actually, the result was much worse and the international trade collapsed with these "beggar-thy-neighbor" policies. "The United States bore some responsibility for this turn of events. What started out in 1929 as a legislative attempt to protect farmers from falling agricultural prices led to the enactment of higher import duties across the board in 1930. The Hawley-Smoot tariff of that year pushed already high protective tariffs much higher and triggered a similar response by other countries. [...] The HawleySmoot tariff in the United States was the signal for an outburst of tariff-making activity in other countries”. See Irwin, Mavroidis, Sykes, 2008, p. 6).

${ }^{7}$ Ruggie (1982, p, 397) reminds that "[i]n the spring of 1947, the U.S. delegation arrived in Geneva armed with congressional authorization for an overall tariff reduction to $50 \%$ of their 1945 levels [...], in return for elimination of preferences. But, at the same time, the United States entered into preferential trade agreements with Cuba and the Philippines".

${ }^{8}$ The word "Latinos" was frequently used by the U.S. delegates in the consulted documents.

${ }^{9}$ NA, “United Nations Conference on Trade \& Employment", Department of Public Information, Havana, Cuba, E/CONF.2/BUR/39U. RG 43, RICCE, Box 139.

${ }^{10}$ NA, Norweb to the Secretary of State, 29 November 1947, RG 43, RICCE, Box 135.
} 
When the Havana Conference took place, several Latin American countries and among them Argentina, Brazil and Mexico, politically and economically the most powerful countries in the region - had already begun the transition from outward-looking economic growth to inward-looking development based on import substitution, with different levels of consistency and success. In the 1930s, in the case of Brazil, or in the 1940s, most Latin American countries became convinced of the importance of economic planning and the development of a national industry. Diversifying their economies was a corollary of the perception of liberal trade relations as governed by a division of labour where industrialized countries were favoured. Argentina was "an exception which proves the rule, since economic diversification had already in this case reduced the weight of primary sector" (Thorp, 1994, p. 119).

Latin Americans countries were highly economically dependent on the U.S., and the opposite was not true. In 1946, the value of American exports (US\$ 13,944 million) was ten times higher than the exports of countries such as Argentina, Brazil and Chile - US\$ 1,753; US\$ 1,652 and US\$ 424 million, respectively. For Argentina, Brazil and Mexico, international trade represented US\$110, US\$ 35 and US\$ 40 per capita, respectively, but for the U.S. it corresponded to a non-negligible amount of US\$ 97 per capita. Nevertheless, exports corresponded to a low percentage of the American gross production (8\%), while Argentina, Brazil and Chile were substantially dependent on their exports (37\%, $42 \%$ and $58 \%$ of their GDP, respectively). Combined with the fact that the U.S. was the main importer of Latin American products, these conditions made them deeply dependent on American markets and their goodwill, which remained commercially and financially attached to the U.K.

Table 2 - Trade Figures - 1946

\begin{tabular}{|l|c|c|c|c|}
\hline & $\begin{array}{c}\text { External Trade } \\
\text { million US\$ }\end{array}$ & GDP US\$ & $\begin{array}{c}\text { Trade as } \% \\
\text { of GDP }\end{array}$ & $\begin{array}{c}\text { Trade per } \\
\text { capita US\$ }\end{array}$ \\
\hline Argentina & 1,753 & 4,706 & 37 & 110 \\
\hline Australia & 1,265 & 3,960 & 32 & 169 \\
\hline Bolivia & 125 & - & - & 33 \\
\hline Brazil & 1,652 & 3,940 & 42 & 35 \\
\hline Chile & 424 & 725 & 58 & 78 \\
\hline Mexico & 1,202 & 1,510 & 61 & 40 \\
\hline El Salvador & 46 & - & - & 23 \\
\hline $\begin{array}{l}\text { United } \\
\text { Kingdom* }\end{array}$ & $9,118+$ & $32,500+$ & 28 & 186 \\
\hline United States & 13,944 & 178,200 & 8 & 131 \\
\hline Uruguay & 301 & - & - & 164 \\
\hline Venezuela & 705 & - & - & 97 \\
\hline
\end{tabular}

* Metropolis, Burma, Ceylon, South Rhodesia, other Territories.

Source: E/CONF.2/4. Conference of Trade and Employment, Unrestricted, Note by the Executive Secretary, 29 October 1947. 
The experience of World War II and the shortage of imported manufactured products confirmed the understanding of Latin American countries about their vulnerability as commodity-exporting countries, encouraging new efforts at import substitution. World War II also promoted the U.S. interest in safeguarding and pushing for Latin American countries' supplies of strategic materials - e.g., rubber, manganese, nickel and bauxite - as these countries became the major suppliers of the U.S.

From the beginning of the war, the U.S. strategy for Latin America had a significant economic dimension. It was understood the risks that the region's economic difficulties would bring in terms of maintaining solidarity to the Allied forces. This solidarity and material support was expected to be rewarded with U.S. economic aid after the war, compensating at some point the asymmetries between the U.S. and the Latin Americans countries. "The years 1945-48 were characterized by a continental hope on the Latin American side that substantial U.S. aid would be forthcoming, and continued foot-dragging on the U.S. side" [...] (Thorp, 1994, pp. 130-131).

After the attack on Pearl Harbour, at the end of 1941, the U.S. government demanded that Latin American countries announce a commitment to the Allied cause. In January 1942, at the Conference of American Foreign Ministers in Rio de Janeiro, it was decided that the countries of the continent should sever diplomatic and commercial relations with the Axis powers. Central American countries declared war immediately after the Pearl Harbor attack. Mexico would do it in May 1942. Brazil and Cuba would participate militarily in the war.

In the 1940s, U.S. investment rose in the continent, even if it was low when compared to the investments received by countries of much greater interest to the U.S. Economic cooperation was always a relevant issue in inter-American meetings in this period. In 1940, the Conference of American Foreign Ministers in Panama created the Inter-American Financial and Economic Advisory Commission, which in turn created the Inter-American Development Commission "to stimulate the increase of non-competitive imports to the U.S., intra-Latin American trade and the development of Latin American industry". In 1941, the Conference of American Foreign Ministers in Havana asked to develop commodity arrangements.

In February-March 1945, when the war was almost over with the victory of the Allied forces, the American government was already sending a different signal. At the Inter-American Conference on Problems of War and Peace, in Mexico, the countries of the continent were requested reduce tariffs and welcome foreign capital. Not surprisingly, "[t]he Latin American participants asked whether the first steps should not come from the U.S. or the United Kingdom [...]" (Thorp 1994, pp. 121-122, 131-132).

Therefore, the war gave some ephemeral weight to the U.S.'s continental neighbours. At the same time, it inaugurated a new phase in the U.S.'s relationship with the continent, as Latin American dependence turned out to be much bigger economically and politically. When the Marshall Plan was announced, in July 1947, it had become more clear that no recovery program would be offered by the U.S. 
government ${ }^{11}$, among other reasons because the region was one of the least tense of the international system and not a major focus for the American government. The Inter-American Treaty of Reciprocal Assistance (the Rio Treaty) would be signed in September 1947, but no significant military, technical or financial assistance was offered to Latin American countries either. ${ }^{12}$

The frustration for not receiving what they considered to be a recognition of their cooperation and loyalty during the war reinforced Latin American countries' perception about the existence of a U.S. double-standard treatment:

[t]he U.S. itself, in granting Marshall Aid, was encouraging closer economic links between the European countries. Was there not a contradiction between this regional approach, now endorsed fully by the U.K. and the universal system of non-discrimination that remained the aim of the ITO? (Gardner, 1956, p. 370).

When the ITO Conference began, in November 1947, U.S. economic aid was a remote possibility, and the Latin American government's frustration accompanied their delegations to Havana, a frustration which had already risen due to the extensive trade concessions given to the Britons regarding the Imperial Preferences and other trade issues in their bilateral trade negotiations. ${ }^{13}$

Substantive position cleavages among the negotiators who were involved in the creation of the new international trade regime were multiplied when the multilateral meetings began, amplifying, therefore, the ones that had involved the U.S. and the U.K. in their previous bilateral talks. The U.S. and the U.K. had opposed positions on the agriculture sector: the U.S. wanted to phase out their domestic export subsidies to agriculture, while the Britons intended to keep export subsidies. When finally the "Proposals for Expansion of World Trade and Employment" were published, in December 1945, agriculture had been excluded from the general rules of trade liberalization: quantitative import restrictions and export subsidies were

\footnotetext{
${ }^{11}$ Latin American non-satisfaction and concerns were largely portrayed in U.S. and Cuban newspapers during the Havana Conference. Due to severe balance of payments problems, it was considered that without an equal financial support there was the possibility of developing countries receding to the role of mere importers of manufactured products and exporters of primary products that they had been playing during the war, causing a drastic decrease on capital goods production. AHI, Carlos Alves de Souza (Brazilian ambassador in Havana) to Raúl Fernandes (Minister of External Relations), 8 March 1948 Reserved Telegram, n. 65. Conference on Trade and Employment, Brazilian delegation, Ofícios (Received), March 1947 to March 1948.

12 "In 1950 Latin America was the only area of the world without a US aid program, apart from meagrely funded Point Four technical assistance program established in 1949. Against the US\$49 billion in US foreign aid to Western Europe in the period 1945-50, only US\$400 million (less than 2 percent of total US aid) went to Latin America. Belgium and Luxembourg alone received more than the whole Latin America" (Bethell and Roxborough, 1992: 22).

${ }^{13}$ In the end, the Havana Charter provisions and the GATT agreed on the permission of preferential agreements.
} 
permitted. Raising revenue to subsidize their agriculture would not be feasible for Latin American countries (Douglas, Mavroidis, Sykes, 2008, pp. 70, 76-77). ${ }^{14}$

Economic development and diversification was indeed a key issue for Latin American countries, and import substitution played a part in their attitudes in Havana. Nevertheless, a commitment to import substitution was far from being their only concern. Developing countries as a whole had faced significant external shocks along the three decades that preceded the Havana Conference. The volatility in commodity markets and the related difficulties were a major concern of developing countries (Scott, 2009, p. 2). As a Brazilian negotiator would comment several decades later:

the creation of a trade organization should have as one of its main responsibilities the issue of price stabilization for primary products, for this instability was at the root of the balance-sheet difficulties of primary producers. This basically involved, however, the problem of agriculture, a sector which has always witnessed tenacious protectionism, which nowadays [1994] threatens the very survival of the GATT (Campos, 2001, p. 109).

organização de comércio deveria ter como uma de suas responsabilidades principais o problema da estabilização dos preços de produtos primários, pois essa instabilidade estava na raiz das dificuldades de balanço dos produtores primários. Isso envolvia, entretanto, basicamente o problema da agricultura, setor que sempre provocou um protecionismo tenaz, que nos dias de hoje [1994] ameaça a própria sobrevivência do GATT (Campos, 2001, p. 109).

Official documents of the Havana Conference, American diplomatic papers and the contemporary press show that Latin American delegations not only identified themselves as a group, but were also perceived as an active group with relevant common interests. Despite differences in behaviour, it was not rare that a Latin American delegate would speak on behalf of the others in committee meetings and informal discussions. Among these countries, Brazil, Chile, Cuba, Uruguay, Mexico and Argentina were perceived as the most active and prominent. ${ }^{15}$

Concerning Brazil, Chile and Cuba, this could be explained, among other things, by the fact that they were the only Latin American countries that took part in the New York, London and Geneva Preparatory Meetings, being more politi-

\footnotetext{
${ }^{14}$ In 1951, the U.S. Congress confirmed and enlarged agricultural support legislation that would allow applying quotas for import control. The exception for export subsidies was an omen of the approval of the American waiver in the GATT for pursuing domestic price support programs, in 1955. The American waiver would have even more far-reaching consequences, and that was ultimately not removed. Besides, it would become the legal basis for the European claims that the Common Agricultural Policy (CAP) did not defy GATT rules (Goldstein, 1993; Kim, 2010).

${ }^{15}$ India, China, Australia and Lebanon were others very active developing countries in the Conference (Capling, 2001, 15).
} 
cally and technically able to work on the issues in discussion in Havana. ${ }^{16}$ Thus, Americans expected these countries to be more committed to the ITO Charter since they had been "intimately associated with and through their participation in the Preparatory Committee meetings". Brazil and Cuba were considered the most conciliatory and moderate, while Argentina had the widest visibility due to the extremely aggressive speeches of its representatives. ${ }^{17}$

And when the Conference was concluded, although some rules better suited to their own preoccupations were introduced, their perception was that the ITO Charter did not correspond to their economic needs (Gardner, 1956, p. 379).

If a general rejection of the international trade Charter had already been noticed at the Havana meeting opening, at its end the U.S. perception was that "Latin American delegations [...] [created] many difficulties and, on many points, expressed $[. .$.$] sharp disagreement with basic U.S. positions". { }^{18}$ Furthermore,

To varying degrees all Latin American delegations accused the U.S. of a lack of sympathy with legitimate Latin aspirations, whether or not they were convinced that the U.S. lacks sympathy. [...] The Latin American submitted a number of specific arguments to prove the foregoing U.S. actions: 1. "The ITO Charter is devoted to protection of the U.S. and the industrialized countries." [...] 2. "The United States has aligned itself with Europe against Latin America." [...] The United States has been unwilling to consider dispassionately and sympathetically Latin American amendments. ${ }^{19}$

Ten years after the enactment of the GATT, it had become clear that the developing countries' perception that they were not profiting from the new order deserved serious attention. In this context, a group of experts ${ }^{20}$ was chosen to study the specific situation of the developing world. This group produced the Harbeler Report, of 1958, which pointed out the challenges the trade system faced and made suggestions to address them. The Report stated that

${ }^{16}$ The participants of the Geneva Preparatory Meeting are the 23 founding Contracting Parties of the GATT, among which only three are Latin American: Australia (then a developing country), Belgium, Brazil, Burma, Canada, Ceylon, Chile, China, Cuba, Czechoslovakia, France, India, Lebanon, Luxembourg, Netherlands, New Zealand, Norway, Pakistan, Southern Rhodesia, Syria, South Africa, United Kingdom and the United States.

${ }^{17}$ NA, "Analysis of Latin America Proposals, Tactics and Employment (Havana, 21 November 1947 to 24 March 1948)," J. Robert Schnetzel (Technical Secretary, US Delegation) Secret, 30 March 1948. RG 43, Records of International Conferences, Commissions, and Expositions (RICCE), Box 148.

${ }^{18}$ NA, "Analysis of Latin American Positions at ITO Conference in Habana with Particular Reference to Bogota,” J. Robert Schnetzel, 24 March 1948. RG 43, RICCE, Box 145.

${ }^{19}$ NA, “Analysis of Latin America Proposals, Tactics and Employment (Havana, at November 1947 to March 1948),” J. Robert Schnetzel, US delegation, March Washington DC, Secret, 30 March 1948.

${ }^{20}$ Gottfried Haberler, Roberto Campos, James Meade and Jan Tinbergen. 
there is some substance in the feeling of disquiet among primary producing countries that the present rules and conventions about commercial policies are relatively unfavourable to them [and] it would be unwise to count upon any improvement in the terms of trade of the non-industrial countries to raise their ability to purchase imports (GATT, 1958, pp. 11-12).

The Report was an early indicator that the GATT was about the behaviour of developed countries, as it concluded that existing arrangements were relatively unfavorable to primary producing countries (Hudec, 2010).

\section{INEQUALITIES IN THE MAKING}

Actually a case can be made by the fact that the Latinos are basically right: they have a gripe, they are not getting what they want, nor will they get it. We have been getting what we want and have been able to a large extent to separate them and to knock them off at a time.

J. Robert Schnetzel ${ }^{21}$

Even if the developing countries and among them the "solid block" of the Latin American countries ${ }^{22}$, ITO Charter would be an expression of the clear-cut advantages of developed over developing countries. For four years, from August 1941 to August 1945, the U.S. and the U.K. discussed postwar trade policy. After stalemates and delays, when the war was over, it took more than two months for the public release of the Proposals for Expansion of World Trade and Employment, in December 1945. The political and technical knowledge acquired during these long and close U.S. and U.K. trade talks would not be easily challenged by the delegations that would participate in the preparatory meetings that would follow, in 1946 and 1947, which "would be highly technical in character, requiring the services of persons competent in the various specialized fields [...] [emphasis added]". ${ }^{23}$

Of the 57 delegations in Havana, only 18, a third of them, had attended the

\footnotetext{
${ }^{21}$ NA, “Analysis of Latin America Proposals, Tactics and Employment (Havana, 21 November 1947 to 24 March 1948)", J. Robert Schnetzel (Technical Secretary, US Delegation), Secret, 30 March 1948. RG 43, Records of International Conferences, Commissions, and Expositions (RICCE), Box 148.

22 "In the official account on the Havana Conference, Wilgress, the head of the Canadian delegation, provides us with a very interesting personal evaluation of the situation [...] In his view, the Latin American countries were able to act as a 'solid block' [...]. They were quite unhappy with the fact that the U.S. government had decided to help European countries only [Marshall Plan]." See Douglas, Mavroidis, Sykes (2008, p. 121).

${ }^{23}$ Foreign Relations of the United States, 1946, vol. 1, pp. 1280-1289. Memorandum Prepared in the Division of Commercial Policy Preparations for Preliminary International Meeting on Trade and Employment, Confidential, Washington, February 6, 1946, apud Douglas, Mavroidis, Sykes (2008, p. 166).
} 
preparatory meetings, three of which were from Latin America: Brazil, Chile and Cuba. Therefore, the majority of the delegations that met in Havana for the International Conference of Trade and Employment in October 1947 would barely do more than acknowledging the issues in discussion. Despite the visibility of some Latin American countries at the Conference, their ability to act occasionally as a group could not be compared to the U.K.'s capacity to form coalitions with their subjects. As seen before, once they obtained key concessions from the U.S. in their 1945 bilateral negotiations, the U.K. successfully insisted that negotiations should continue in a multilateral forum, where, with its allies, it would outnumber the U.S. "by a factor of five to one".

There are a number of other aspects that explain lack of bargaining power of several developing countries, such as the low number of representatives, the poor quality and efficiency of their public functions when compared to the U.S. and to the European countries and the misfortune of not speaking English, the working language of the negotiations, as their native tongue.

Brazil, Cuba and Chile were far from having the smallest delegations. Cuba was a clear exception among developing countries and specifically among Latin American countries. Being the host of the international meeting allowed Cuba to have one of the largest delegations.

\section{Number of delegates}

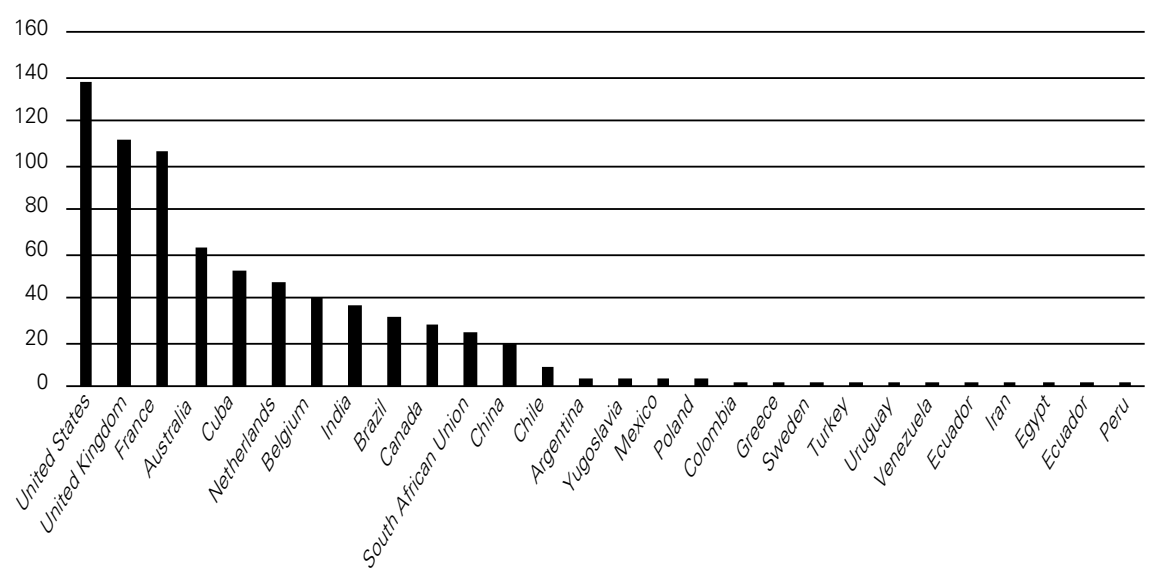

Source: United Nations, Economic and Social Council (ECOSOC), E/PC/T/35, 8 April 1947.24

\footnotetext{
${ }^{24}$ The delegations numbered as follows (including general service personnel, such as secretaries): Argentina, 3; Australia, 63; Belgium/Luxemburg, 37/3; Brazil, 32; Canada, 27; Chile, 9; China, 20; Colombia, 2; Cuba, 52; Ecuador, 1; France, 106; Greece, 2; India, 36; Iran,1; Egypt, 1; Ecuador, 1; Yugoslavia, 3; Mexico, 3; Netherlands, 47; Poland, 3; Peru, 1; South African Union, 24; Sweden, 2; Turkey, 2; United States,138; United Kingdom, 112; Uruguay, 2; Venezuela, 2. Cf. United Nations, ECOSOC, E/PC/T/35, 8 April 1947.
} 
Developing countries did not have the same degree of sophistication and efficiency in public functions when compared to the public administration of the U.S. and European countries. In Latin America, Argentina, Brazil, Chile and Uruguay were in an intermediate position concerning public administration and services. Still, in October 1947, in the days preceding the opening of the Conference, the chief of the Brazilian delegation reported to the Brazilian minister of External Relations that

[o]ur administrative resources, means of investigation and data are too inadequate for this kind of negotiation. [We are not] supported, for the solutions to our trade politics problems that we [are going] to debate, by a general plan of the national economy - simply because there is no such plan. ${ }^{25}$

Latin American countries fought for making Spanish a second working language at the Conference. In what the straight-talking U.S. negotiators called the "Spanish language battle", these countries won a "partial victory" when it was agreed that some facilities would be provided at the Plenary Session, such as "whispering translators" and important documents translated into Spanish. It should be noted that English became a working language in international meetings due to the rising international prominence of the U.S. after the beginning of the $20^{\text {th }}$ century. Until then, French had been the diplomatic tongue, largely spoken by the Latin American elite, such as diplomats.

Relatively poor political and technical knowledge, as well as the low number of representatives coming from countries where English was not the official language and where the public administration was inefficient, made developing countries weak negotiators in Havana. They did not always understand the meaning of substantive and procedural clauses in discussion. The result was that these substantive and procedural requirements for the application of clauses mostly associated to the developing countries' demands were far more restrictive than the exceptions related to developed countries' interests. Exceptions related to developed countries' interests, for example, did not require the prior approval of the ITO, nor could they be subject to the veto of any country. On the other hand, the prior approval of the ITO was necessary to apply the economic development exceptions demanded by developing countries, as observed by Hudec (1987, p. 23).

Then,

$[\mathrm{p}]$ rocedure was often the key to the compromise. The developing countries usually obtained some recognition of the principle that "economic development" could be a legitimate reason for using trade-distorting measures prohibited by the Charter. The United States usually obtained additional

\footnotetext{
${ }^{25}$ AHI-Rio, Antônio de V. Ferreira-Braga to Raul Fernandes (Minister of External Relations), Ofício, acompanha o "Relatório Preliminar sobre as Negociações do Acordo Geral de Tarifas e Comércio, Genebra,” October 10, 1947.
} 
substantive criteria limiting the scope of the exceptions and procedural conditions and requirements designed to limit application of the exception to only the very clear cases (Hudec, 1987, p. 23; emphasis added).

The Latin American opposition would only grow until it became the most consistent source of resistance to the terms of negotiations, something that the American delegates were sometimes inclined to interpret as mere stubbornness. The "Latin American economic theory" or the Latin American countries' "industrialization fixation" can be considered to be the issue that synthesized the opposition that emerged between the American and Latin American delegations in Havana. Americans were correct when noting that that was the "motivating force behind the bulk of the Latin American amendments". ${ }^{26}$

At the end of January 1948, after acknowledging the intention of the "Latino caucus" to present a letter to the Conference insisting on the request for the creation of a new committee, Americans would comment that "after two months of [American] patient exposition and accommodation, the Latinos acknowledge nothing. [T]o say what we think and oppose would cause a bad atmosphere and an irreparable breach in the Conference". ${ }^{27}$

However, at the same time, Americans realized that the fact that a number of the Latin American delegations felt that their specific problems were not seriously taken into consideration was a threat to the conclusion of the Conference. Hence, although irritated, Americans negotiators made efforts to dissipate these impressions. They did not give up and they strove for a good, cooperative relationship with Latin American delegates, not missing out on opportunities such as luncheons and dinners to persist in trying to convince them about the validity and the benefits of a liberal trading system.

The ITO architects had in their mind the Smoot-Hawley Tariff Act and a conviction regarding its awful consequences: trade protectionism during the 1930s had led the world to a terrible war. Nevertheless, the developing world as a whole was inserted in quite a different historical context. Among them, Latin American countries had gone through, during the war, a lack of industrialized goods they could not import, as well as restrictions on their exports. In addition, they had to sell commodities to the U.S. at fixed prices. When the war ended, there were no price controls for importing U.S. industrial goods, while commodity exports underwent a steep downturn which resulted in severe BoP deficits.

In addition to opposing the American liberal economics perspective for these immediate and concrete needs, Latin American countries had a long historic background to underlie their points in Havana. These countries had adhered to a neoclassical economic orientation when they became independent in the $19^{\text {th }}$ century. However, since the beginning of the $20^{\text {th }}$ century and especially from the 1930 s on,

\footnotetext{
${ }^{26}$ NA, "Economic Views of Latin American Delegations", Secret, Havana, no date, RG 43, RICCE, Box 39.

${ }^{27}$ NA, “Minutes of U.S. Delegation Meeting,” Confidential, 31 January 1948. NA, RG 43 RICCE, Box 148.
} 
nationalism and conceptions about the central role of governments in promoting industrialization to escape underdevelopment had grown in appeal. These became some of the key ideas of the strong Latin American social thought that would prevail for decades to come.

Furthermore, countries that had most important trade relations with the U.S., as was the case of Latin American countries - Argentina being an exception - had seen how the U.S. had protected itself in the 1930s with the Smoot Hawley tariff. Nonetheless, Latin American countries also saw how the United Kingdom's Imperial Preference System suppressed competition.

During the years of the Depression, Latin American governments had seen the U.S. and U.K. following protectionist measures, and some of them were even trying to adopt a substitution of the imports model. Consequently, in Havana, there was a battle among countries with great asymmetries in material power.

\section{CONCLUSION}

"We lost the fight.” Roberto Campos (2001), referring to the
negotiations at the Havana Conference (1947-1948)

This article aimed at offering a different perspective from the mainstream historiographic interpretation of the Havana Conference, which negotiated and approved the Charter of the ITO, including the GATT. It focused on the participation of a group of non-hegemonic countries, the Latin American countries. It claimed that the concept of embedded liberalism, applied for qualifying and understanding the new international trade regime, obscures other visions than the American- and European-centered. Additionally, Ruggie's concept of embedded liberalism is directly linked to his definition of multilateral institutions. It was emphasized that the starting point for the delimitation of embedded liberalism in the case of trade negotiations took place in bilateral talks between U.S. and U.K. officials, not in a multilateral forum, resulting in the "Proposals for Expansion of World Trade and Employment", which were published at the end of 1945. This would become the starting point for the following multilateral negotiations that were completed in Havana.

Latin American countries recognized the U.S.'s legitimacy in constructing the post-Word War II international economic order. However, at the same time, despite their respective specificities and differences, there was among them a common perception that the Havana negotiations would be most of all the expression of the interests of developed countries. To start, Latin American countries believed that diversifying their economies was their more relevant challenge and objective, which was at odds with the liberalization brought on by the new trade regime. They believed that their fragile economies should face the strong economies of the developed with economic planning and import substitution, which had already been in place in several Latin American countries since the 1930s and the 1940s. The disdain showed by some U.S. 
officials in disqualifying Latin American apprehensions as an "industrialization fixation" showed that they could not recognize the conflict of interest.

What is more, Latin American countries' economies were extremely dependent on the U.S., and World War II had exacerbated this condition. Supplying strategic materials was these countries' main contribution to the Allied forces. Coinciding with the beginning of the Havana Conference, the Marshall Plan was also announced, making it clear that the expected U.S. economic plan for Latin American countries had become more than remote. Thus, the Havana talks began for them as a symbol of frustration, as it was when they ended. On the one hand, being commodity-exporting countries, one of most important issues for them were the creation of mechanisms to protect their economies from the volatility in commodity markets, in which they did not succeed. On the other hand, the establishment of quantitative import restrictions and the creation of export subsidies to agriculture were permitted, which would be detrimental to Latin American economies.

Material and political constraints limited Latin American countries' negotiating capacity, meaning they were unable to shape the new international trade rules to their advantage or to emerge as important players in the international trade regime. This study called attention to some aspects that limited the quality of these countries' participation in post-Word War II trade negotiations, such as the low number of representatives in their delegations, the poor quality and efficiency of their public functions when compared to the U.S. and to the European countries, and their relatively weak political and technical knowledge of several substantive and procedural clauses in negotiation.

Only the GATT survived, and this study may help to understand, at least in part, the relative lack of Latin American countries' interest in truly participating in its regime during the first decades of its existence, a blow that was also felt by other developing countries.

\section{REFERENCES}

Aaronson, Susan (1996) Trade and the American Dream: A Social History of Postwar Trade Policy. Lexington: University Press of Kentucky.

Bethell, Leslie and Roxborough, Ian (eds.) (1992) Between the Second World War and the Cold War, 1944-1948. Cambridge (UK): Cambridge University Press.

Brown, William A. (1950) The United States and the Restoration of World Trade: an Analysis and Appraisal of the ITO Charter and the General Agreement on Tariffs and Trade. Washington: Brookings Institution.

Campos, Roberto (2001) Lanterna na Popa: Memórias. 4. ed., vol.1. Rio de Janeiro: Topbooks.

Capling, Ann (2000) "The 'Enfant Terrible': Australia and the reconstruction of the multilateral trade system, 1946-48”, Australian Economic History Review, 40 (31): 1-21.

Capling, Ann (2001) Australia and the Global Trade System. From Havana to Seattle. Cambridge: Cambridge University Press.

Curzon, Gerard (1969) La Diplomacia del Comercio Multilateral. México: Fondo de Cultura Económica.

Deese, David (2008) World Trade Politics: Power, Principles, and Leadership. London/New York: Routledge. 
Diebold, Jr., William (1952) “The end of the ITO”, Essays in International Finance, n ${ }^{\circ}$ 16, International Finance Section. Princeton: Princeton University.

Elkin, Natan (1984). Los Paises Latinoamericanos frente el GATT. Washington, D.C.: BID-INTAL,

Evans, John W. (1968) “The general agreement on tariffs and trade”, International Organization, 22 (1): 72-98.

Farias, Rogério de S. (2012), Industriais, Economistas e Diplomatas: o Brasil e as Negociações Comerciais Multilaterais (1946-1967), PhD dissertation, Instituto de Relações Internacionais, Universidade de Brasília.

Farias, Rogério de SouzaI (2014), "Brazil and the origins of the multilateral trading system”, The International History Review, vol. 37: 303-323.

Feis, Herbert (1948), “The Geneva proposals for an international trade charter”, International Organization, 2 (31): 39-52.

Gardner, Richard N. (1956), Sterling-Dolar Diplomacy. Anglo-American Colaboration in the Reconstruction of Multilateral Trade. Oxford: The Clarendon Press.

Goldenstein, Judith (1993) "Creating the GATT rules: Politics, institutions, and American policy". In John G. Ruggie (ed.). Multilateralism Matters, The Theory and the Práxis of an Institutional Form. New York: Columbia University Press, pp. 201-232.

Hudec, Robert (2010) Developing Countries in the GATT Legal System. 2 ed. Cambridge: Cambridge University Press.

GATT, Secretariat (1958) "Trends on international trade: a report by a panel of experts" (Haberler Report). GATT Digital Library (http://gatt.stanford.edu).

Griffiths, Martin; Roach, Steven C., Solomon, M. Scott (2008) Fifty Key Thinkers in International Relations. 2. ed. New York: Routledge.

Irwin, Douglas A. (1995) “The GATT in historical perspective", The American Economic Review, 85 (2), Papers and Proceedings of the Hundredth and Seventh Annual Meeting of the American Economic Association Washington, D.C., pp. 323-328.

Irwin Douglas A.; Mavroidis, Petros C.; Sykes Alan O. (2008) The Genesis of the GATT. New York: Cambridge University Press.

Keohane, Robert (1986) "Reciprocity in international relations", International Organization, 40 (1): $1-27$.

Kim, Soo Yeon (2010), Power and the Governance of Global Trade: From the GATT to the WTO. Ithaca (NY): Cornell University Press.

Lipson, Charles (1983) "The transformation of trade: the sources and effects of regime change", In Stephen Krasner (ed.) International Regimes. Ithaca/London: Cornell University Press: 233-271.

Miller, James N. (2000) "Origins of the GATT: British resistance to American multilateralism", Jerome Levy Economics Institute at Bard College, Cambridge University Working Paper $\mathrm{n}^{\circ} 318$.

Miller, James N. (2003) Wartime Origins of Multilateralism, 1939-1945: The Impact of the Anglo-American Trade Policy Negotiations, Ph.d. thesis, Emmanuel College, University of Cambridge.

Polanyi, Karl (2001 [1944]), The Great Transformation: the Political and Economic Origins of our Time. 2. ed. Boston: Beacon Press.

Ruggie, John G. (1982) "International regimes, transactions, and change: embedded liberalism in the post-war economic order", International Organization, 36 (2): 379-415.

Ruggie, John G (1992) “Multilateralism: the anatomy of an institution”, International Organization, 46 (3): 561-598.

Ruggie, John G (2003) Constructing the World Polity: Essays on International Institutionalisation. London: Routledge.

Scott, James (2009) "Developing countries in the ITO and GATT negotiations", Manchester: Brooks World Poverty Institute, Working Paper 95.

Thorp, Rosemary (1995) “The Latin American economies, 1939-c.1950”, In Leslie Bethell (ed.), The Cambridge History of Latin America, vol. VI. Latin America since 1930: Economy, Society and Politics, pp. 117-158.

Zeiler, Thomas W. (1999) Free Trade, Free World, the Advent of GATT. Chapel Hill: The University of North Carolina Press.

Wilcox, Clair (1949) A Charter for World Trade. New York: The Macmillan Company. 